\title{
The Quality Management System as a Driver of Organizational Culture: An Empirical Study in the Portuguese Textile Industry
}

\author{
DOI: 10.12776/QIP.V23I1.1132
}

Romeu Araújo, Gilberto Santos, José Batista da Costa, José Carlos Sá

Received: 04 July 2018 Accepted: 04 February 2019 Published: 31 March 2019

\begin{abstract}
Purpose: The purpose of this paper is to analyse the Portuguese textile industry in which way quality culture influences the organization's performance. Thus, it was created an investigation model made up of three hypotheses. The aim was to obtain the interconnection among "error detection culture, error anticipation culture, creative culture, and continuous improvement, and finally performance".
\end{abstract}

Methodology/Approach: A questionnaire tested before in similar studies (Cameron and Sine, 1999; Costa, 2008; Leal, Roldan and Acedo, 2002), was sent to 71 companies. The questionnaire was structured in three sections. The geographic area chosen for analysis was the North of Portugal. Were received 60 valid answers, which represents a sample with a percentage of $84.5 \%$ of useful answers.

Findings: The results show that the existence of strong interconnections for the "error detection culture negatively influences performance" and for the "creative culture and continuous improvement" positively influences performance. Many companies of this research are managed according to reactive quality cultures. They are still oriented by values and attributes that should be improved in the paradigm of quality management.

Research Limitation/implication: The study is limited to a geographic area, designated Northern Portugal.

Originality/Value of paper: From the obtained results it was found the existence of a dominant quality culture (the error detection culture). This means that Portuguese textile industries, and others industries in another countries, with the "error detection culture", are oriented by quality values which must be improved. 
Category: Research paper

Keywords: quality culture; performance; textile industry; TQM; Portugal

\section{INTRODUCTION}

The textile industry has large representativeness in the Portuguese industrial structure, highlighting the important role it plays in terms of employment. This activity represents enormous volatility in the economic performance due to oscillations verified between offer and demand on a global scale (Vasconcelos, 2006). it undergoes. A few years ago, this type of industry had a restructuring phase due to the strong competitive pressure created by cheap labour economies. The change in the economic paradigm, the fast-paced transformation of consumer's preferences and the evolution of technology were another problems. All these factors have demanded from textile companies a new competitive dynamics and flexibility, both in what concerns the products, as well as, the productive processes and management structures according to ATP (Textile Association of Portugal, 2018).

In order to answer to market demands, the textile sector has been registering dynamic and competitive behaviours over the past two years. Advantages of its strengths were highlighted, such as, the geographic and cultural closeness to the European market, "the tradition and textile culture" and know-how, moderate salary costs when compared to European standards, the growing international recognition of products, the execution of several investments of technological modernization and the growing development of a culture of quality.

Quality is identified as a strategic element that generates added value (Santos, Mendes and Barbosa, 2011; Doiro et al., 2017; Murmura and Bravi, 2017; Carvalho, Santos and Gonçalves, 2018). Moreover, the added value that is generated during the activity of quality improvement is recognized as a tool which helps to regulate market share, to coordinate and to satisfy the needs of stakeholders and to receive economic benefit (Daunoriene and Staniskiene, 2016; Santos and Barbosa, 2006; Bravi, Murmura and Santos, 2017; Santos, Bravi and Murmura, 2018). Customer oriented quality fulfils customers' needs and expectations and highlights suitability for use (Hermans and Liu, 2013). All this happens, preserving the environmental issues (Ribeiro et al., 2017; Santos et al., 2015; Rebelo, Santos and Silva, 2017; Barbosa, Oliveira and Santos, 2018), where it appears new business models with new digital technologies (Santos et al., 2018; Bravi, Murmura and Santos, 2018; Santos, Murmura and Bravi, 2018), with the intention of improving the quality of life (Bravi, Murmura and Santos, 2018; Felix et al., 2018). According to several authors (Rebelo, Santos and Silva, 2015; Santos et al., 2014; Santos, Rebelo and Santos, 2017) the integration of quality with others different Management Systems, such as, environmental, safety and others, represent added value both in the present and, fundamentally, for the future, not only for the company, as well as for a whole range of 
stakeholders allowing for the enhancement of sustainable development of organizations. The present study aims at identifying which types of quality culture in the Portuguese textile industries profess and how these influences the performance of organizations.

\section{THE CULTURES OF THE COMPANY}

Quality from fundamental philosophical perspective can be defined as the summary of entity property manifestation in surrounding and time their characteristic functions (Zgodavová et al., 2002). For culture and quality to be linked together, it is necessary to recognize the potential impact that the former, as a system of norms, values, and practices, reflects in the quality system. It can be joined together as a sustainable competitive advantage in organizations. The company culture, textile or not, is made by people. Hence, human resources are the most valuable resource of any company or country, but not always the most valued. Thus, the greatest asset of any organization, of any region or any country, is the people with their know-how (Santos et al., 2013; Rebelo et al., 2016; Santos and Milán, 2013; Marques et al., 2018).

By perceiving quality in a TQM process and its results in performance, derived from its implementation, literature presents divergent opinions, both of success and failure.

In a positive perspective, they have the quality circles, lean production, the production techniques, and the quality control procedures to increase the product quality (Flynn, Roger and Sadao, 1995; Garvin, 1988). Delta Consulting Group (1993) and Easton and Jarrel (1998) analyzed 44 organizations and concluded that the TQM implementation programs positively influence the organizations output.

On the other hand, from a negative perspective, research conducted in several countries reported that initiatives of quality implementation failed to meet their targets (Young, 1992).

Empirical studies in the textiles sector conducted in SMEs indicate the benefits of TQM implementation, but they are referred to a set of difficulties. The component "organizational culture" is highlighted as a means to TQM success too (Middleton, 2004; Towers and McLoughlin, 2005).

In the same line of thought, Green (2012) identifies some problems in the implementation of TQM process and suggests that success depends mostly on the "organization culture". So he presents four models of organizational culture, which could influence the implementation of TQM and thus get a positive impact on performance.

Cameron and Sine (1999) developed a research work and characterized current company cultures within organizations in quality culture typologies. Leal, Roldan and Acedo (2002) and Costa (2008) tested Cameron and Sine's model to prove 
whether different quality cultures make TQM easier and influence the performance of organizations. The research was conducted following the path of that author.

\subsection{Quality Culture according to Cameron and Sine (1999)}

Cameron and Sine (1999) conducted a study on the organizational culture of quality on the grounds of clarifying the reasons behind the failure associated with several initiatives of quality and its ambiguous relationship with performance. This study was validated with empirical analysis throughout three years to a universe of 68 organizations.

Due to the incongruence of definitions, dimensions and impact on the performance of organizations, some scholars started to investigate TQM as a cultural phenomenon, more than a set of tools and techniques.

Cameron and Sine (1999) define the quality culture as the "subset of the global culture of the organization" considering that this reflects the general approach, the values and the orientation towards quality that cross-organizational actions.

The authors in the analysis present four different typologies to characterize the quality culture, according to Tab. 1 .

Table 1 - Quality Culture Types (Adapted from Cameron and Sine, 1999)

\begin{tabular}{|l|l|}
\hline Quality Culture & Characteristics \\
\hline The absence of Quality & $\begin{array}{l}\text { Products } \\
\text { Quality is not a priority; } \\
\text { Quality is not systematically measured; } \\
\text { Quality is not tied to the organizational strategy; }\end{array}$ \\
\cline { 2 - 2 } & $\begin{array}{l}\text { Customers } \\
\text { The organization is not focused on customers; } \\
\text { It is not receiving feedback from customers; } \\
\text { The organization is not responsive to customers; }\end{array}$ \\
\hline \multirow{5}{*}{ Error Detection } & Products \\
& Avoid mistakes; \\
& Reduce waste, rework, and repair; \\
& Detects problems; \\
& The focus is on outputs; \\
\cline { 2 - 2 } & Customers \\
& Avoid annoying customers; \\
& Respond to complaints efficiently and accurately; \\
& Assess satisfaction after the fact; \\
& Focus on needs and requirements; \\
\hline
\end{tabular}




\begin{tabular}{|c|c|}
\hline Quality Culture & Characteristics \\
\hline \multirow[t]{2}{*}{ Error Prevention } & $\begin{array}{l}\text { Products } \\
\text { Expect zero defects; } \\
\text { Prevent errors and mistakes; } \\
\text { Hold everyone accountable; } \\
\text { Focus on processes and root causes; }\end{array}$ \\
\hline & $\begin{array}{l}\text { Customers } \\
\text { Satisfy customers and exceed expectations; } \\
\text { Eliminate problems in advance; } \\
\text { involve customers in design; } \\
\text { Focus on preferences or "nice-to-have" attributes; }\end{array}$ \\
\hline \multirow[t]{2}{*}{ Creative Quality } & $\begin{array}{l}\text { Products } \\
\text { Continuously improve and escalate standards; } \\
\text { Concentrate on things-gone-right; } \\
\text { Emphasize breakthroughs; } \\
\text { Focus on improvement in suppliers, customers, and } \\
\text { processes; }\end{array}$ \\
\hline & $\begin{array}{l}\text { Customers } \\
\text { Expect lifelong loyalty; } \\
\text { Surprise and delight customers; } \\
\text { Anticipate expectations and create new preferences. }\end{array}$ \\
\hline
\end{tabular}

As it can be analyzed on Tab. 1, Cameron and Sine (1999) identify on their typology, a quality culture which would be convenient to call "of non-quality", as it can exhibit a total absence of emphasis on quality. Here one can find some organizations that pay little or no attention to quality as a differentiating element. Quality is not seen as a strategy or organizational goal. Values, habits, and behaviours of this type of organizations do not include quality. Nevertheless, such does not mean that the products or services do not have quality. However, these authors emphasize that from a strictly cultural point of view, there is also a shortage of criteria, such as, norms, rules, procedures, attitudes, aims and principles that characterize an organization and its culture.

When it comes to the quality paradigm, there are three types of culture. One is considered reactive, characterized by "error detection", on which, quality is addressed as a problem to be solved or by a set of potential obstacles to be avoided. Another, which is characterized by "error prevention" and which approaches quality with a proactive attitude concerning problems. The difference is drawn up by avoiding mistakes instead of correcting them after pinning them up.

On top of quality cultures identified by the authors comes the "creative quality" in which, all the strategy of the organization is centered on quality. The constant growth of quality patterns, as well as output levels, are the key goals of this type of culture. In these organizations, there is a total involvement from all its members, aiming at promoting a quality culture of excellence. With these 
convictions considered at this level, the recognition is promoted by TQM. The global functioning of an organization, or its final result, meet the two last out of seven definitions of quality-focused by Cameron and Sine (1999). Those are consistent with the "Big Q" approach of quality from Juran (1988): "Quality is a system of means to economically produce goods or services which satisfy customer`s requirements" (Japanese Industrial Standards Committee, 1981). Or "Quality means that the organization's culture is defined by and supports the constant attainment of customer satisfaction through an integrated system of tools, techniques, and training" (Sashkin and Kiser, 1993). These different types of quality culture can be considered representative of different maturity levels of quality.

An important conclusion that emerged from this study points out that the most advanced quality cultures had higher performance levels than less developed cultures. Another conclusion of this study reports that each quality culture is characterized by having a single set of tools and techniques.

The changes in organizational culture seem to be both desirable and possible. An essential challenge from leaders in organizations is to manage the cultural change process. A change from a quality culture of "error detection" into an "error prevention culture" can produce better improvements in quality and organizational efficiency than any individual change of techniques.

This empirical study was conducted with the purpose of clarifying the different types of quality culture and its impact on performance. On analyzing the introduction of quality improvement programs or TQM in organizations, without being accompanied by a cultural change, it can be concluded that the probability of failure becomes high.

\subsection{Quality Culture according to Leal, Roldan and Acedo (2002)}

This study was based on Cameron and Sine's (1999) research about quality culture and on which they decided to analyze 113 Spanish companies, from which $62 \%$ are industrial companies and $20 \%$ belong to the services sector.

The TQM implementation requires the existence of an organizational culture receptive to change, based on the motivation of both the staff all company to aim for improvement. It is also befitting that people are willing to get involved, understand and later implement a particular group of principles, techniques and TQM practices.

On establishing a parallelism between Leal, Roldan and Acedo (2002) and Cameron and Sine (1999) on quality culture levels, one can observe that they classify their study in "three types of culture", instead of four levels, highlighting "error detection culture, error anticipation culture, creative culture, and continuous improvement".

The organizations that were the object of analysis in this study demonstrated that they all fitted in a type of culture, without the predominance of one of the quality 
cultures. However, according to Cameron and Sine (1999) when an organization concentrates more (in relative terms) in a culture of error detection, that is because it is a less developed culture as Tab. 2 demonstrates. On the other hand, when more emphasis is given to error anticipation culture and creative culture and continuous improvement, these are characterized by "cultures with the highest quality level."

Table 2 - Types of Quality Culture (Adapted from Leal, Roldan and Acedo, 2002)

\begin{tabular}{|l|l|l|}
\hline & Concerning Products & Concerning Customers \\
\hline $\begin{array}{l}\text { Error } \\
\text { Detection }\end{array}$ & $\begin{array}{l}\text { Inspect and detect errors; } \\
\text { Reduce waste, the costs of } \\
\text { breakdowns and faults; } \\
\text { Centered on results and products. }\end{array}$ & $\begin{array}{l}\text { Avoid troubling to customers; } \\
\text { Answer complaints rapidly and firmly; } \\
\text { Reduce dissatisfaction; } \\
\text { Centered on the customers "needs". }\end{array}$ \\
\hline $\begin{array}{l}\text { Error } \\
\text { Anticipation }\end{array}$ & $\begin{array}{l}\text { Anticipate errors; } \\
\text { Seek zero defects; } \\
\text { Design the first time correctly; } \\
\text { Centered on processes and causes } \\
\text { of errors. }\end{array}$ & $\begin{array}{l}\text { Satisfy customers expectations; } \\
\text { Help customers by avoiding future } \\
\text { problems; } \\
\text { Obtain customers preferences } \\
\text { beforehand and follow them; } \\
\text { Centered on customers "preferences". }\end{array}$ \\
\hline $\begin{array}{l}\text { Creative } \\
\text { Culture and }\end{array}$ & $\begin{array}{l}\text { Improve normal performance } \\
\text { parameters; } \\
\text { Create new alternatives; } \\
\text { Concentrate on things being done } \\
\text { well; }\end{array}$ & $\begin{array}{l}\text { Surprise and delight customers; } \\
\text { Be committed to compensating } \\
\text { customers; } \\
\text { Anticipate customer's expectations; } \\
\text { "Create" customer preferences. }\end{array}$ \\
& $\begin{array}{l}\text { custered on suppliers and } \\
\text { as on processes. }\end{array}$ & \\
\hline
\end{tabular}

In literature, there is enough evidence about the relationship between TQM and the performance of organizations.

Other authors point out that the TQM implementation system does not quite often produce the expected results because most TQM work is centered on its implementation factors and tools, and forget that a set of values and beliefs underlie all TQM implementations, in other words, some philosophy or cultural orientation. Starting from the hypothesis that the "quality culture is positively related TQM performance programs" three sub-hypothesis arise, according to Fig. 1:

H1. The error detection culture is positively related the TQM program performance.

H2. The error anticipation culture is positively related to the TQM program performance.

H3. The creative culture is positively related to the TQM program performance. 


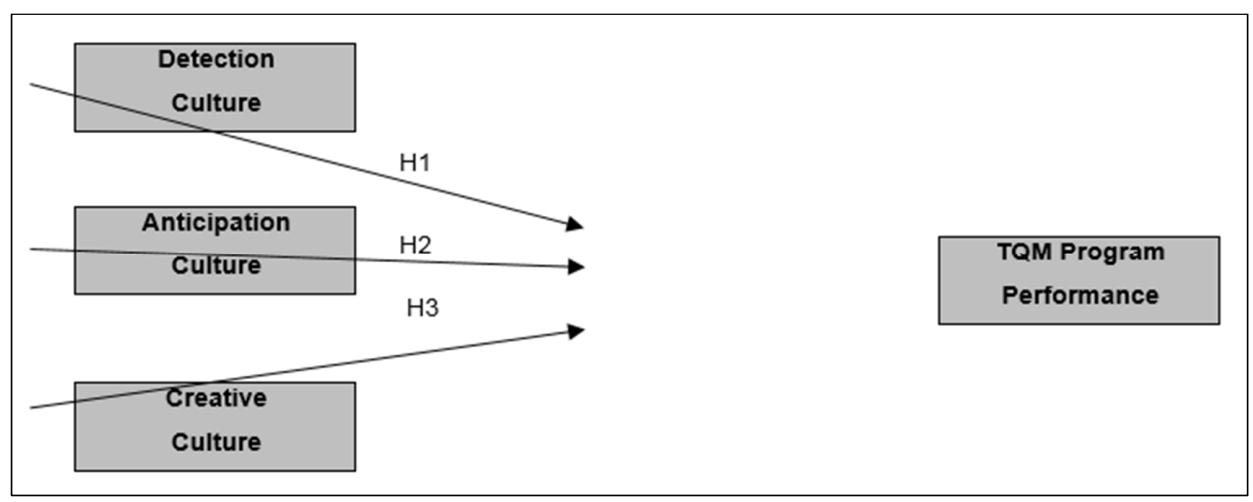

Figure 1 - Model of Investigation and Hypothesis

(Adapted from Leal, Roldan and Acedo, 2002)

On designing the questionnaire to measure the three types of quality cultures, Cameron's model was followed. This allows eight different items to each culture, and these consist in attributes that qualify the way in which enterprises manage TQM principles in search of total quality. Like the original questionnaire, the respondents divided 100 points among the corresponding items to the three scenarios, according to the importance or emphasis they gave them in practice. From Cameron's aims, which consisted in an attempt to identify a dominant culture through an additive operation, the items correlation or their internal consistency was not an assumption. These authors decided to define indicators as formative according to each type of culture, that is, indicators where their reason for cause is not observed in theoretical constructions. On the other hand, the performance of the quality program is associated to a scale adapted from Powell (1995), which consists in five measure points, from 1 "totally disagree" to 5 "totally agree".

From the analysis of the obtained results, one confirms the existence of considerable high cultures (error anticipation $58.9 \%$ and creative culture $11.6 \%$ ); however, there is still a critical percentage of $29.5 \%$ companies that emphasize the type of culture known as "error detection", which focus the workers' attention in obsolete values and attributes.

Out of this study, we concluded that organizations should focus their efforts to generate a higher culture as the culture of error detection, negatively influences the performance of the TQM program, which explains $33 \%$ of the criterion variation. On the other hand, both cultures of anticipation and creative culture present a connection with TQM programs, showing an explained fluctuation of $10.79 \%$ and $11.16 \%$ respectively of the dependent variable. The top management must assume an important role in the promotion of more advanced cultures in all levels of the organization and lead the processes of change, both at human resources level and strategies in a way to internalize the values of the "creative culture". 


\subsection{Quality Culture according to Costa (2008)}

An empirical study was also conducted in Portugal, following Cameron and Sine's lines of work, as well as, those of Leal, Roldan and Acedo (2002). The latter author proposed to analyze the quality management systems in Portuguese companies, including the topic of the importance of quality cultures and its impact on performance in his work.

The sample used is formed by 260 certified companies, both industries, and services, distributed through several activity sectors, being that textile, building and metallurgy sectors which represent $24.6 \%, 15.4 \%$, and $12.7 \%$ respectively. It is relevant to mention the importance of the textile sector in the regional economy. The types of culture professed in the questionnaire by this author were, according to Tab. 3, "the error detection culture, the error anticipation culture and the creative culture and continuous improvement."

Table 3 - Percentage of Different Types of Culture (Adapted from Costa, 2008)

\begin{tabular}{|l|r|}
\hline Quality Culture Typology & Percentage \\
\hline Error Detection Culture & $38.37 \%$ \\
\hline Error Anticipation Culture & $51.02 \%$ \\
\hline Creative Culture and Continuous Improvement & $10.61 \%$ \\
\hline Total & $100.00 \%$ \\
\hline
\end{tabular}

The results of the previous study testify the existence of different quality cultures, with emphasis on the majority (51.02\%) of the "error anticipation culture", though there is still a relevant number $(38.37 \%)$ of companies that continue to emphasize the type of "error detection culture", which attests that they are still oriented by values and attributes that can be improved. With a weight of $10.61 \%$, the "creative culture and continuous improvement" culture demonstrate that few organizations develop this type of culture, sustaining the obtained results from other studies (Leal, Roldan and Acedo, 2002; Cameron and Sine, 1999).

The companies with an "error detection culture" adopt a strategy of "results reinforcement" regulating TQM through gradual or incremental changes, implementing small changes in specific parts of its organization, depending on results which are expected to be achieved.

In a different perspective, companies that are oriented by the "error anticipation culture" adopt a "reorientation - activity" strategy, which professes the TQM as a more radical change and in large scale over the whole organization, whose implementation involves a new way of doing, thinking, negotiating, and brings out a cultural change in the whole organization. It becomes necessary to reinvent the organization. 
In the same line of action, the "creative culture and continuous improvement" establishes higher proximity with TQM and its consequent positive impact on performance. The same was checked in the study of Leal, Roldan and Acedo (2002), which indicates that organizations should guide their efforts towards this type of culture. This happens as it is advised that organizations find a way of exceeding the performance and standard expectations and put emphasis on startling and delighting the client.

In concomitance with this study, Leal, Roldan and Acedo (2002) testified Cameron's structure and also concluded that the "error detection culture" negatively influences performance. On the other hand, the "error anticipation culture" and the "creative culture and continuous improvement" establish a positive correlation with performance. The management of organizations must promote more advanced quality cultures (error anticipation culture, creative culture, and continuous improvement) as these are the ones which promote a more significant impact on performance.

\section{METHODOLOGY}

The investigation started with the formulation of a questionnaire based on an existing model tested and validated by other authors, such as Cameron and Sine (1999), Leal, Roldan and Acedo (2002), and Costa (2008).

The questionnaire was structured in three sections. In the first section, one questions the number of existing employees within an organization, so that it can fit and define the dimension of industries according to the European Commission (2003). The second section qualifies the quality program on "performance" and is measured through 5 items, each one using the Likert scale of five points, where the first point means "much disagreement" and the last point means "much agreement". Lastly, on section three, how companies position themselves in terms of quality towards TQM demand, (error detection culture, error anticipation culture, and creative culture and continuous improvement) the types of culture were measured through 24 items, where they are represented, the error detection culture, the error anticipation culture, the creative culture and continuous improvement. These measure scales were used by Cameron and Sine (1999), Leal, Roldan and Acedo (2002) and Costa (2008).

The questionnaire was sent to 71 companies. Some companies did not respond. There were also some questionnaires which were not complete. Thus, the sample is formed by 60 textile companies which represent a ratio of the useful answer of $84.5 \%$. The geographic area chosen for analysis was the North of Portugal, namely "Vale do Ave", as there is a strong "textile culture" in this region and a considerable part of Portuguese textile industries. Important institutions connected to the textile sector are located there, namely the Technological Centre of Textile and Clothing Industries of Portugal (CITEVE), the Textile and 
Clothing Association of Portugal (ATP) and the Centre of Textile Science and Technology of Minho University.

According to studies from Cameron and Sine (1999), Leal, Roldan and Acedo (2002), and Costa (2008), one confirmed that different types of quality culture mean different levels of maturity in quality. Thus, the higher culture is, the bigger its impact is on performance. These works concluded that being TQM a performance generator process, this has more or less implantation success according to the quality culture emanated by the organisation. Through the formulation of the three hypotheses, the existing types of culture in the Portuguese textile firms were evaluated. It was measured the performance of the quality program, with the aim of understanding which types of quality culture should profess the Portuguese industries, in order to gain raises in performance.

\section{HYPOTHESES FORMULATION AND MODEL OF INVESTIGATION}

Following the conclusions drawn from the analyzed studies, it can be said that TQM produces positive results and generates value for organizations, causing a rise in the performance of organizations.

From the professed cultures in Cameron and Sine's study (1999), which were used in other researches, such as, Leal, Roldan and Acedo (2002) and Costa (2008) (error detection culture, error anticipation culture, creative culture and continuous improvement), the results were unanimous when it comes to produced effects by culture in the implementation of the TQM program. Thus, companies with an "error detection culture" negatively influence the TQM performance, unlike the "error anticipation culture" and the "creative culture and continuous improvement", positively influence the TQM performance.

Without alluding to performance, managers cannot, in an objective or consistent way, assess the quality of their decisions (Chakravarthy, 1986). In brief, considering that the bigger or, the smaller success of the TQM implementation depends largely on the type of existing quality culture, as this is a management system generator of performance, one assumes that the higher the culture of the existing company is, the bigger its performance is.

Hence, it can be understood if the culture of the company influences performance, specifically on the impact on productivity, on the competitive position, on the improvement of profitability, on profit, among other factors. As such, the following hypotheses were formulated, according to the Fig. 2:

H1. The error detection culture negatively influences performance.

H2. The error anticipation culture positively influences performance.

H3. The creative culture and continuous improvement very positively influence performance. 


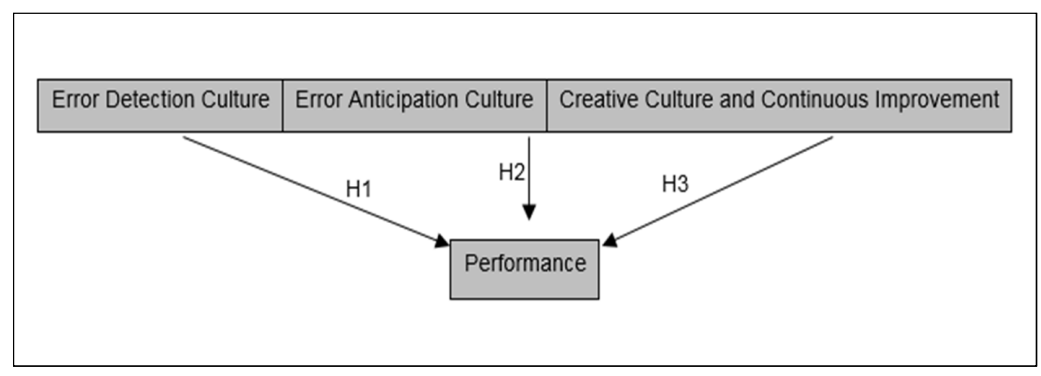

Figure 2 - Model of Investigation and Hypotheses (Araújo, 2014)

\section{RESULTS}

\subsection{Number of Workers}

The following analysis allows us to confirm the number of companies: up to 10 workers (micro companies), from 10 to 49 workers (small companies), from 50 and 249 workers (medium companies) and more than 250 workers (big companies).

In the sample, the number of workers of the companies in study presents an average value of 118 employees with a value dispersion of $162 \%$. The values, minimum and maximum are 5 and 900 workers, respectively.

The number of workers of the studied companies is analyzed according to its dimension. To get this rating, one used the number of workers as a reference to compare with other studies, so one resorted to intervals in the European Commission recommendation, from 6 May (European Commission, 2003).

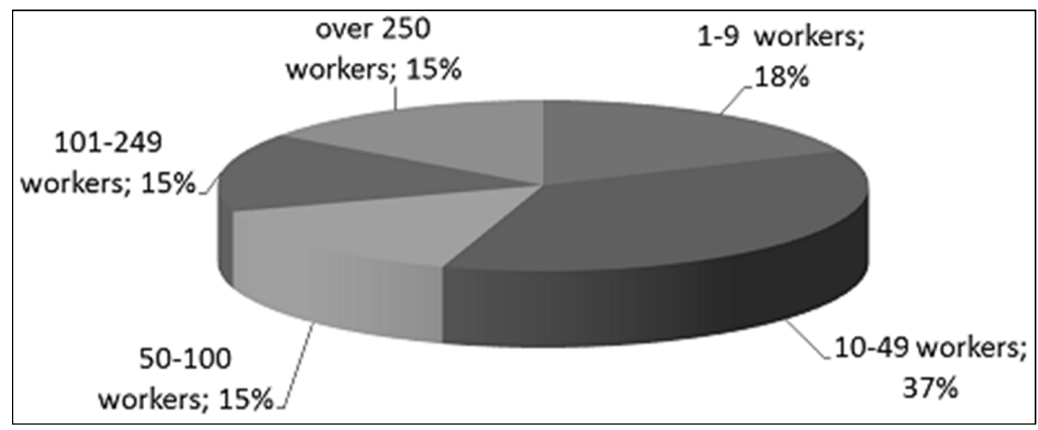

Figure 3 - Distribution of Workers according to the Company

Dimension (Araújo, 2014)

In terms of analysis, the enterprise universe is characterized by the dominance of SMEs (85\%), according to the sample in Fig. 3, where $18 \%$ are micro companies, $37 \%$ are small companies, $30 \%$ are medium companies, and only $15 \%$ are big companies. 


\subsection{Performance}

Fig. 4 shows the observed average values according to the importance of a quality program on performance.

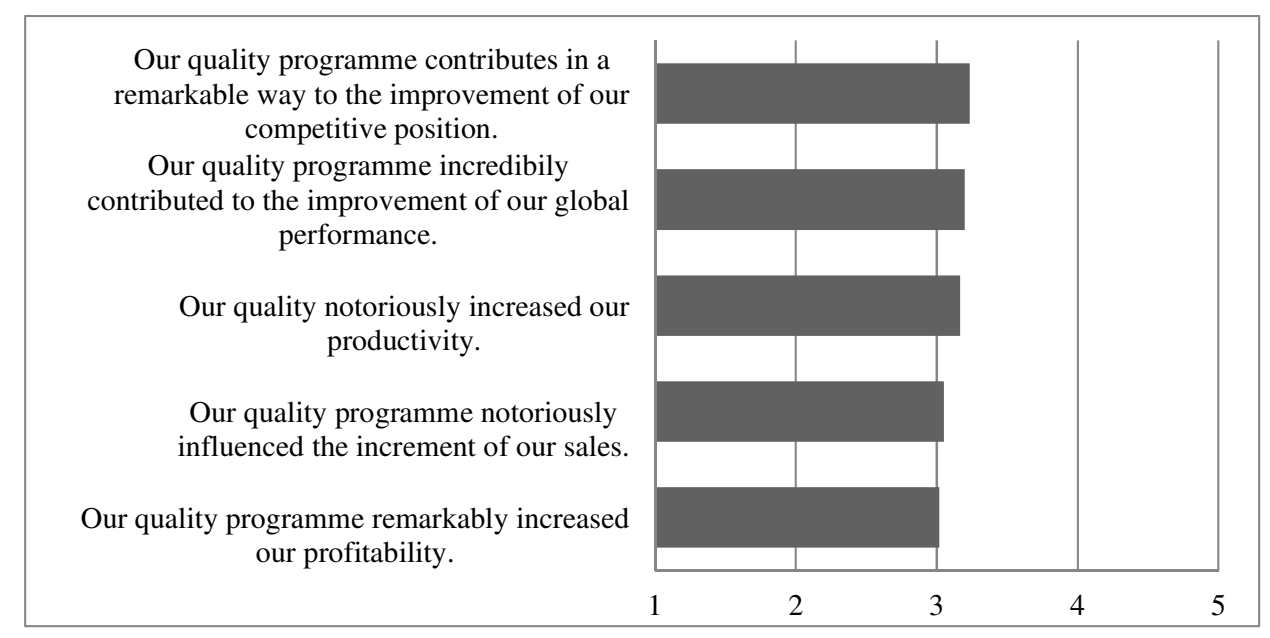

Figure 4 - Distribution of the importance of quality on performance

(Araújo, 2014)

From the observed values, one can highlight the three highest average values, which are "Our quality program contributes in a remarkable way to the improvement of our competitive position", "Our quality program incredibly contributed to the improvement of our global performance" and "Our quality program notoriously increased our productivity".

From this analysis, one concludes that a large part of the sample is aware of capital gains of a quality program and its competitive advantages and the impact that this can have on performance.

In the sample, performance holds an average value of 3.24 (in a measurement scale from 1 to 5) with a dispersion of values of $37 \%$. The minimum and maximum values are 1.00 and 5.00 respectively.

The histogram of the Fig. 5 illustrates the value distribution of performance of the organizations in the study. 


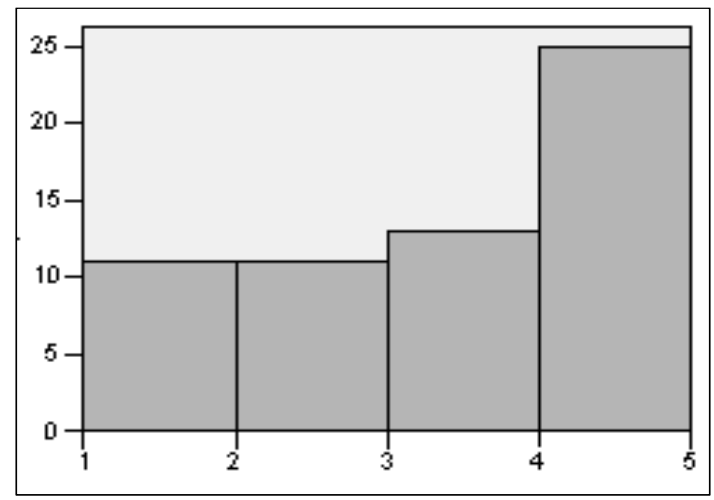

Figure 5 - Histogram of the Number of

Companies Relative to Performance

(Araújo, 2014)

It can be observed that the distribution of performance values is confirmed mainly between 4 and 5 followed in a relatively uniformed way for the other unit intervals.

According to the theoretical revision of the companies in the analysis, a large part of them refers that the performance of organizations depends on the impact of the quality program and how it is implemented and managed.

\subsection{Culture}

In Tab. 4, the mean values observed are presented, according to the distribution of the characteristics of the three types of quality culture.

Table 4 - Distribution of the Characteristics of the Three Types of Quality Culture (Araújo, 2014)

\begin{tabular}{|l|l|c|}
\hline $\begin{array}{l}\text { Quality } \\
\text { Culture }\end{array}$ & Typology Description & Mean \\
\hline Error & & \\
$\begin{array}{l}\text { Detection } \\
\text { Culture }\end{array}$ & 1a. Inspect and detect errors & $\mathbf{9 . 2 5}$ \\
& 2a. Reduce waste, the costs of breakdowns and faults & $\mathbf{7 . 3 3}$ \\
& 3a. Correct errors & 5.80 \\
& 4a. Centred on results and products & 3.70 \\
& 5a. Avoid troubling customers & 5.83 \\
& 6a. Answer complaints rapidly and firmly & 4.97 \\
& 7a. Reduce dissatisfaction & 5.20 \\
& 8a. Centred on the customers "needs" & 2.20 \\
\cline { 2 - 3 } & Total points & 44.28 \\
\hline
\end{tabular}




\begin{tabular}{|c|c|c|}
\hline $\begin{array}{l}\text { Quality } \\
\text { Culture }\end{array}$ & Typology Description & Mean \\
\hline \multirow[t]{2}{*}{$\begin{array}{l}\text { Error } \\
\text { Anticipation } \\
\text { Culture }\end{array}$} & $\begin{array}{l}\text { 1b. Anticipate errors } \\
\text { 2b. Seek zero defects } \\
\text { 3b. Design correctly the first time } \\
\text { 4b. Centered on processes and causes of errors } \\
\text { 5b. Satisfy customers expectations } \\
\text { 6b. Help customers by avoiding future problems } \\
\text { 7b. Obtain customers preferences beforehand and follow them } \\
\text { 8b. Centered on customers "preferences" }\end{array}$ & $\begin{array}{l}\mathbf{9 . 5 2} \\
3.52 \\
4.17 \\
3.85 \\
\mathbf{9 . 1 3} \\
2.27 \\
2.10 \\
2.22\end{array}$ \\
\hline & Total points & 36,78 \\
\hline \multirow[t]{2}{*}{$\begin{array}{l}\text { Creative } \\
\text { Culture and } \\
\text { Continuous } \\
\text { Improvement }\end{array}$} & $\begin{array}{l}\text { 1c. Improve normal performance parameters } \\
\text { 2c. Create new alternatives } \\
\text { 3c. Concentrate on things being done well } \\
\text { 4c. Centered on suppliers and customer's management as } \\
\text { much as on processes } \\
\text { 5c. Surprise and delight customers } \\
\text { 6c. Be totally committed to compensating customers } \\
\text { 7c. Anticipate customers' expectations } \\
\text { 8c. "Create" customer preferences }\end{array}$ & $\begin{array}{l}6.20 \\
2.22 \\
1.50 \\
2.25 \\
\\
1.40 \\
0.53 \\
2.20 \\
2.65\end{array}$ \\
\hline & Total points & 18.95 \\
\hline
\end{tabular}

The four mean values more often observed belong to the types of the culture of "error detection and error anticipation" were, according to Tab. 4, 1b. anticipate errors, 1a. inspect and detect errors, 5b. satisfy customers expectations and $2 \mathrm{a}$. reduce waste, the costs of breakdowns and faults.

One can see in Fig. 6 that the dimension of the dominant culture is the "error detection culture", followed by "error anticipation culture" and lastly by the "creative culture and continuous improvement" culture. It was determined for each company the dimension of the dominant culture, choosing the dimension that presents the higher average value.

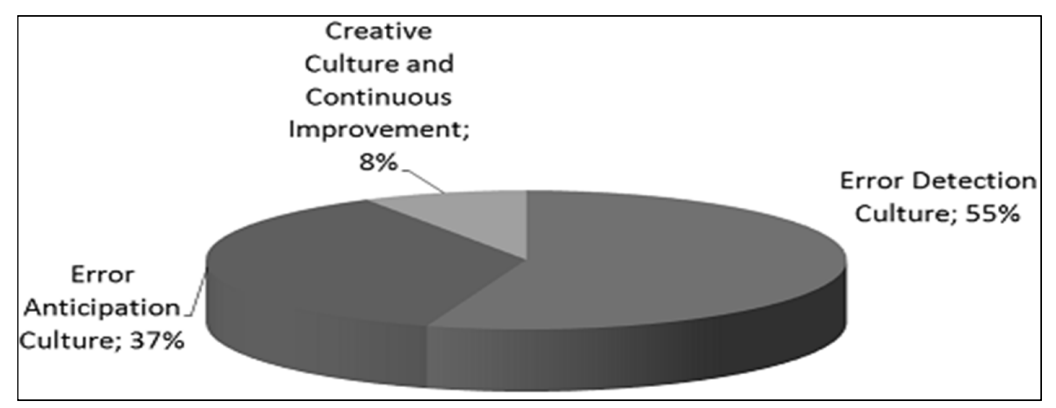

Figure 6 - Percentage of Companies Related to the Type of

Dominant Culture (Araújo, 2014) 
In terms of target analysis on the sample, there are 33 companies that use the "error detection culture", which corresponds to 55\% of companies; 22 companies use the "error anticipation culture", which corresponds to $37 \%$ of companies; and 5 companies use the "creative culture and continuous improvement", which corresponds to $8 \%$ of companies.

This analysis follows the described studies where one finds a predominance of the error detection culture and error anticipation culture using the same measurement scales.

In this research, considering the $55 \%$ of companies with error detection culture and according to with the described literature, it is understood that most companies advocate reactive quality cultures, which denotes that they are still oriented by values and attributes that should be improved in the paradigm of quality management. We are talking about cultures, which do not promote TQM, so the impact of this culture negatively influences the performance (Leal, Roldan and Acedo, 2002; Costa, 2008).

\subsection{Existing Correlation between the Types of Culture and the Performance (Hypothesis Checking)}

All variables whose relation one aims to study are quantitative variables, so they can be analyzed using Pearson's R correlation coefficient.

In Tab. 5, for each line that relates the variables, one shows the Pearson coefficient value and evidential value of the test. The correlations between the types of culture and performance are presented.

Table 5 - Correlation between Types of Culture and Performance (Araújo, 2014)

\begin{tabular}{|l|l|c|}
\hline \multicolumn{2}{|l|}{} & Performance \\
\hline \multirow{4}{*}{$\begin{array}{l}\text { Error Detection Culture } \\
\begin{array}{l}\text { Error Anticipation } \\
\text { Culture }\end{array}\end{array}$} & Coeff. Correlation & $-0.420^{(* *)}$ \\
\cline { 2 - 3 } & Proof Value & 0.001 \\
\cline { 2 - 3 } & $\mathrm{N}$ & 60 \\
\cline { 2 - 3 } & Coeff. Correlation & 0.081 \\
\hline \multirow{2}{*}{$\begin{array}{l}\text { Creative Culture and } \\
\text { Improvement }\end{array}$} & $\mathrm{N}$ & 0.537 \\
\cline { 2 - 3 } & Coeff. Correlation & 60 \\
\cline { 2 - 3 } & Proof Value & $0.456(* *)$ \\
\cline { 2 - 3 } & $\mathrm{N}$ & 0.000 \\
\hline
\end{tabular}

Notes: ** Strong correlation to a significance level of 0.01 . 
Meaningful correlation between the two variables is pointed out (present a proof value inferior to $5 \%$ ). The two statistically meaningful correlations can be:

- Positive, meaning that an increase of a variable corresponds to a significant increase of another.

- Negative, meaning that an increase of a variable corresponds to a significant decrease of another.

- One sees a statistically meaningful relation between:

- Error detection culture and performance;

- Creative culture and continuous improvement and performance.

The checking of hypothesis of the investigation are:

H1. The error detection culture negatively influences performance: One confirms HI, as the error detection culture negatively influences performance, with a correlation coefficient of -0.420.

H2. The error anticipation culture positively influences performance: This hypothesis cannot be confirmed as the error prevention culture is not related to output in a statistically meaningful way and the correlation coefficient is 0.081 .

H3. The creative culture and continuous improvement very positively influences performance: One confirms hypothesis $\mathrm{H} 3$ as the creative culture and continuous improvement positively influences performance, with a correlation coefficient of 0.456 .

Thus, one confirms that the Portuguese textile companies must change their management paradigm, abandon the "error detection culture" and adopt the "creative culture and continuous improvement", so as to positively influence performance.

\section{DISCUSSION}

Considering the weaknesses of definitions, dimensions and inconsistent impacts on performance, Cameron and Sine (1999) investigated TQM as a cultural phenomenon, rather than a set of tools and techniques, realizing that the successful implementation of TQM techniques depends on the internal quality of the organization.

This internal quality of the organization is conditioned by its culture. The key advantage of handling quality as a cultural variable is that the ambiguity and the inconsistency associated with multiple definitions and TQM definitions diminish. To Cameron and Sine (1999) the different types of quality cultures can be considered as representative of different levels of quality maturity (Costa, 2008). 
In line with this vision, Leal, Roldan and Acedo (2002) tested Cameron's structure having also concluded that the error detection culture negatively influences the performance of the TQM program.

On the other hand, the error anticipation culture and the creative culture and continuous improvement have a positive correlation with the TQM program. In Portugal, Costa (2008), in his investigation to industries, obtained the same results.

The hypotheses presented in this study, represent the different types of quality culture, as representing the different degrees of maturity of the organization when it comes to the way these positions in terms of quality. The hypotheses that the culture of error detection has a significant and very negative impact on performance is confirmed, ratifying H1 hypothesis with a coefficient of -0.420.

An error anticipation culture has a positive impact, though not meaningful, on performance, not confirming the $\mathrm{H} 2$ hypothesis. The non-significance of this hypothesis can occur from the fact that the sample size of companies is reduced.

On the other hand, the creative culture and continuous improvement influence very positively and in a meaningful way the performance, confirming $\mathrm{H} 3$ hypothesis with a coefficient of 0.456 . These results meet other studies such as Leal, Roldan and Acedo (2002), Cameron and Sine (1999) and Costa (2008).

Thus, one can say that according to the type of quality culture that comes from each organization, it affects either negatively or positively the output of the organization.

From the developed investigation, it can be concluded that:

The error detection culture negatively influences performance; the creative culture and continuous improvement very positively influences performance;

It is hardly possible to confirm in a meaningful way the hypothesis, which connects the error prevention culture with performance. This hypothesis must be deepened in further studies.

\section{CONCLUSIONS}

At the present, companies are confronted with constant changes in the markets where they operate. Thus, management philosophies, such as TQM are management processes that should be proactively applied, so that textile industries can remain and compete in more and more demanding and globalized markets.

In this study, a model of investigation formed by 3 hypotheses is exposed, so that they can be used as the reference for the Portuguese textile industries, aiming at improving quality in management to make it bear fruit with a positive impact on performance. 
In this perspective, Cameron and Sine (1999) presented four typologies of quality cultures: "absence of emphasis on quality, error detection, error prevention, and creative culture". In further studies, such as Leal, Roldan and Acedo (2002) to 113 Spanish companies, and Costa's (2008) to 260 Portuguese companies, quality cultures were analyzed in three typologies: "error detection culture, error anticipation culture, and creative culture and continuous improvement". From the confirmed results, one concluded in these studies that companies must promote high-quality cultures, such as creative culture and continuous improvement, that facilitate the implementation of continuous improvement tools. It is also relevant that the higher the quality culture is, the higher the positive impact on the performance of organizations it has. On the contrary, the error detection culture negatively influences performance.

This study results point out a predominance $(55 \%)$ of the "error detection culture", that is, it focuses attention in values and attributes that must be improved in the paradigm of quality management. $37 \%$ of companies emphasize the type of error anticipation culture and only a few organizations developed a quality culture up to the level of creative culture and continuous improvement. This is in line with other studies (Leal, Roldan and Acedo, 2002; Cameron and Sine, 1999; Costa, 2008).

The most advanced quality cultures ("error anticipation culture" and "creative culture and continuous improvement") are more related to performance than a less developed culture (error detection culture). The latter presenting a significant negative influence of -0.420 . In the opposite direction, the creative culture and continuous improvement have a positive significance of 0.456 .

This study contributes to conclude that different types of quality cultures are representative of different levels of maturity in quality and have an impact on the performance of the organization (Cameron and Sine, 1999; Costa, 2008; Leal, Roldan and Acedo, 2002). Conclude also that performance is influenced by the level of the predominant quality culture and quality cultures act as the engine of the quality management process due to the effects they exert on performance.

This study allows us to take a set of useful conclusions for the management of the Portuguese textile industry so that the top management will assume an important role in the promotion of more advanced quality cultures at all levels of the organization. These must evolve to creative culture and continuous improvement values.

In practical terms, this study can allow managers to identify the practices that add value to products/services and consequently, positively influence performance.

\section{ACKNOWLEDGEMENTS}

The authors would like to thank all the companies that replied to the questionnaire. 


\section{REFERENCES}

Araújo, J.R.S., 2014. Benchmarking and Company Culture: Impact on income in the Portuguese Textile Industries. Master. Barcelos, Portugal: Instituto Politécnico do Cavado e Ave (IPCA).

ATP-Textile Association of Portugal, 2018. Associacao Textil e Vestuario de Portugal. Available at: <http://www.atp.pt/> [Accessed 22 March 2019].

Barbosa, L., Oliveira, O. and Santos, G., 2018. Proposition for the alignment of the integrated management systems (quality, environmental and safety) with the business strategy. International Journal for Quality Research, 12(4), pp.925-940.

Bravi L., Murmura, F. and Santos, G., 2018. Manufacturing Labs: where new digital technologies help improve life Quality. International Journal for Quality Research, 12(4), pp.957-974.

Bravi, L., Murmura, F. and Santos, G. 2017. Attitudes and Behaviours of Italian 3D Prosumer in the Era of Additive Manufacturing. Procédia Manufacturing, 13, pp.980-986. http://dx.doi.org/10.1016/j.promfg.207.09.095.

Cameron, K. and Sine, W., 1999. A Framework for Organizational Quality Culture. Quality Management, Journal, Administrative Science Quarterly, 6(4), pp.7-25.

Carvalho, F., Santos, G. and Gonçalves, J., 2018. The disclosure of information on sustainable development on the corporate website of the certified Portuguese organizations. International Journal for Quality Research, 12(1), pp.253-276.

Chakravarthy, B.S., 1986. Measuring strategic performance. Strategic Management Journal, 7(6), pp.437-458.

Costa, J.A.B., 2008. Sistemas de Gestión de la Calidad en las Empresas Portuguesas: Implantación, Impacto y Rendimiento. PhD. Seville: University of Seville.

Daunoriene, A. and Staniskiene, E., 2016. The Quality Costs Assessment in the Aspect of Value Added Chain. Quality Innovation Prosperity, 20(2), pp.119-144. http://dx.doi.org/10.12776/QIP.V20I2.746.

Delta Consulting Group, 1993. Ten years after: Learning about total quality management. New York: Delta Consulting Group.

Doiro, M., Fernández, J., Félix, M. and Santos, G., 2017. ERP - machining centre integration: a modular kitchen production case study. Procédia Manufacturing, 13, pp.1159-1166. http://dx.doi.org/10.1016/j.promfg.2017.09.178.

Easton, G.S. and Jarrell, S.L., 1998. The effects of total quality management on corporate performance: An empirical investigation. Journal of Business, 71(2), pp.253-307. 
European Commission, 2003. Commission Recommendation 2003/361 / EC of 6 May 2003 concerning the definition of micro, small and medium-sized enterprises.

Félix, M.J., Santos, G., Barroso, A. and Silva, P., 2018. The transformation of wasted space in unban vertical gardens with the contribution of design to improving the quality of life. International Journal for Quality Research, 12(4), pp.803-822.

Flynn, B., Roger, S. and Sadao, S., 1995. The impact of quality management practices on performance and competitive advantage. Decision Sciences, 26(5), pp.659-691.

Garvin, D.A., 1988. Managing quality: The strategic and competitive edge". New York: Free Press.

Green, T.J., 2012. TQM and organisational culture: How do they link?. Total Quality Management \& Business Excellence, 23(2), pp.141-157.

Hermans, J.E. and Liu, Y., 2013. Quality Management in the New Product Development: A PPAP Approach. Quality Innovation Prosperity, 17(2), pp.3751. http://dx.doi.org/10.12776/QIP.V17I2.150.

Japanese Industrial Standards Committee, 1981. Industrial Standardization Z8101. [online] Available at: $<$ https://www.iso.org/member/1835.html?view=participation\&t=PT $>$ [Accessed 01 March 2019].

Juran, J.M., 1988. On Planning for Quality. London: Collier Macmillan.

Leal, A., Roldan, J.L. and Acedo, F.J., 2002. Quality Culture and Performance: a Cameron's Framework test in spanish companies. In: EURAM (European Academy of Management), 2002. Proceedings of Second Annual Conference on Innovative Research in Mangement. Stockhol, Sweden, 9-11 May 2002. Brussels: EURAM. pp.245-255.

Marques, C., Lopes, N., Santos, G., Delgado, I. and Delgado, P., 2018. Improving operator evaluation skills for defect classification using training strategy supported by attribute agreement analysis. Measurement, 119, pp.129141.

Middleton, D., 2004. The Business Process Revolution in UK Textile Manufacturing. Journal of The Textile Institute, 95(1-6), pp.1-7.

Murmura, F. and Bravi, L. 2017. Empirical evidence about ISO 9001 and ISO 9004 in Italian companies. The TQM Journal, 29(5), pp.650-665. https://doi.org/10.1108/TQM-11-2016-0097.

Powell, T.C., 1995. Total quality management as competitive advantage: A review and empirical study. Strategic Management Journal, 16, pp.15-37. 
Rebelo, M., Santos, G. and Silva, R., 2017. The integration of standardized Management Systems: managing Business Risk. International Journal of Quality \& Reliability Management, 34(3), pp.395-405.

Rebelo, M., Santos, G. and Silva, R., 2015. Integration of Standardized Management Systems: A Dilemma?. Systems, 3(2), pp.45-59.

Rebelo, M., Silva, R., Santos, G. and Mendes, P., 2016. Model Based Integration of Management Systems (MSs) - Case Study. TQM Journal, 28(6), pp. 907-932.

Ribeiro, F., Santos, G., Rebelo, M. and Silva, R. 2017. Integrated Management Systems: trends for Portugal in the 2025 horizon. Procédia Manufacturing, 13, pp.1191-1198.

Santos, D., Rebelo, M. and Santos, G., 2017. The Integration of certified Management Systems. Case Study - Organizations located at the district of Braga, Portugal. Procedia Manufacturing, 13, pp.964-971.

Santos, G. and Barbosa, J., 2006. QUALIFOUND - a modular tool developed for Quality Improvement in Foundries. Journal of Manufacturing Technology Management, 17(3), pp.351-362.

Santos, G., Afonseca, J., Murmura, F., Félix, M.J. and Lopes, N., 2018. Critical success factors in the management of ideas as an essential component of innovation and business excellence. International Journal of Quality and Service Sciences, 3(3), pp. 214-232.

Santos, G., Barros, S., Mendes, F. and Lopes, N., 2013. The main benefits associated with health and safety management systems certification in Portuguese small and medium enterprises post quality management system certification. Safety Science, 51(1), pp.29-36.

Santos, G., Bravi, L. and Murmura, F., 2018. SA 8000 as a Tool for a Sustainable Development Strategy. The Corporate Social Responsibility and Environmental Management Journal, 25, pp.95-105.

Santos, G., Mendes, F. and Barbosa, J., 2011. Certification and integration of management systems: the experience of Portuguese small and medium enterprises. Journal of Cleaner Production, 19(17-18), pp.1965-1974.

Santos, G. and Milán, A.L., 2013. Motivation and benefits of implementation and certification according ISO 9001 - The Portuguese experience. International Journal for Quality Research, 7(1), pp.71-86.

Santos, G., Murmura, F. and Bravi, L., 2018. Fabrication laboratories: The development of new business models with new digital technologies. Journal of Manufacturing Technology Management, 29(8), pp.1332-1357.

Santos, G., Rebelo, M., Barros, S., Silva, R., Pereira, M., Ramos, G. and Lopes, N., 2014. Developments regarding the integration of the Occupational Safety and Health with Quality and Environment Management Systems. In: G.I. Kavouras and M.-C.G. Chalbot, eds. 2014. Developments Regarding the Integration of the 
Occupational Safety and Health with Quality and Environment Management Systems. New York: The Nova Science Publishers. Chapter 6.

Santos, G., Rebelo, M., Lopes, N., Alves, M.R. and Silva, R., 2015. Implementing and certifying ISO 14001 in Portugal: motives, difficulties and benefits after ISO 9001 certification. Total Quality Management \& Business Excellence, 27(11-12), pp.1211-1223.

Sashkin, M. and Kiser, K.J., 1993. Putting total quality management to work. San Francisco: Barret-Koehler.

Towers, N. and McLoughlin, J., 2005. Effective Total Quality Management in the textile fashion retail supply chain: A pilot survey of the UK textile manufacturers. Journal of The Textile Institute, 96(2), pp.87-92.

Vasconcelos, E., 2006. Análise da indústria têxtil e do vestuário. [pdf] Braga, Portugal: EDITVALUE Consultoria empresarial LDA Available et: $<$ http://consultoriaempresarial.editvalue.com/assets/sites/55a8a0b6301be3e68f00 0002/content_entry55a8a2ce301be34700000057/55a8b6b0301be358fe000163/fil es/analise-da-industria-textil-do-vestuario33bb.pdf?1437122223> [Accessed 01 March 2019].

Young, E., 1992. International quality study: The definitive study of the best international quality management practices. Cleveland: Ernst and Young.

Zgodavová, K., Linczényi, A., Nováková, R. and Slimák, I., 2002. Profesionál kvality. Košice: Technická Univerzia v Košiciach.

\section{ABOUT AUTHORS}

Romeu Araújo - is graduated in Accounting by Polytechnic Institute of Cavado and Ave, Portugal (2009). He received Master's degree in Accounting and Organizational Management from the School of Management at the Polytechnic Institute of Cavado and Ave, Portugal. With regard to the professional level, he has developed activity linked to Textile Industry, namely, as agent of brands, in the sale of machines and components. His main research interests include company cultures in quality management and the impact they promote on performance of organizations. E-mail: romeu_araujo@sapo.pt.

Gilberto Santos - is Prof. at Polytechnic Institute Cávado Ave (IPCA) Barcelos, Portugal. He holds a $\mathrm{PhD}$ degree in Mechanical Engineering from Minho University, Portugal. His current research interests include industrial and mechanical engineering, namely, innovation, quality systems and integrated management systems. Gilberto participates as a speaker in several national and international conferences, and he is currently author of several publications in integrated management systems (IMS) - QES (quality, environment and safety) (books, papers in international and national journals). He is member of the research team of several IMS - QES research projects and also supervises Master 
and $\mathrm{PhD}$ thesis, as well reviewer of international journals. Gilberto founded a master's course on "Integrated Management Systems QES" at the College of Technology of Polytechnic Institute Cávado, where he was Director of the MSc during the first six editions. Gilberto Santos is the corresponding author and can be contacted at: gsantos@ipca.pt. Author's ORCID: https://orcid.org/0000-00019268-3272.

José Batista da Costa - is graduated in Electrical Engineering by the University of Porto, Portugal (1977). He received a PhD degree in Business Management by University of Seville (2008), Spain. Presently he is a Professor at College of Management (Polytechnic Institute Cávado Ave) in Portugal. He is author of many communications presented in conferences and congresses. He published many papers as an author in journals. His main research interests include strategy and quality management. E-mail: baptistacosta@outlook.pt.

José Carlos Sá is graduated in Production Engineering from the Minho University (1998). He holds a Master's Degree in Industrial Engineering option: Quality, Safety and Maintenance, by the Minho University (2010). In 2015 he is awarded the title of Specialist in Quality Management, by the Polytechnic Institute of Viana do Castelo. He is currently a PhD student in Industrial and Systems Engineering. José Carlos is a professor at the Engineering School of Porto, at the Polytechnic of Porto, and consultant (since 2004) in several companies, in safety management, quality management and industrial management. In 2015, José Carlos became a "senior member" of the Portuguese Engineer Association. He has made several presentations at various national and international congresses and has published several articles and chapter books on quality management, safety management and lean management. E-mail: cvs@isep.ipp.pt. Author's ORCID: http://orcid.org/0000-0002-2228-5348.

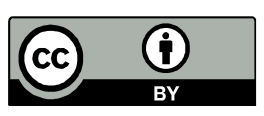

(C) 2019 by the authors. Submitted for possible open access publication under the terms and conditions of the Creative Commons Attribution (CC-BY) license (http://creativecommons.org/licenses/by/4.0/). 